\title{
Berbagai Pendekatan Komunikasi Lintas Budaya Bagi Masyarakat Dayak
}

\author{
Harming \\ Sekolah Tinggi Teologi Simpson Ungaran \\ Email: harming984@gmail.com
}

\begin{abstract}
:
This paper discusses various approaches to cross-cultural communication. This study focuses on Christian communication where this communication model is slightly different from communication in general. Christian communication focuses on discussion of gospel truths conveyed across cultures. In communicating, obstacles often occur due to differences in characteristics, language, perceptions, physicality and culture. If these obstacles are not managed properly, they will cause conflict and have an impact on a person's life and society. The method I use is library research, which is to express ideas and ideas by analyzing various library sources. The analysis process is carried out by means of literature study, namely collecting sources in the form of journals related to cross-cultural communication and books on communication so that an overview is found related to the topics discussed. The results found are various cross-cultural communication approaches that can be used, including the Interpersonal communication approach; approach theory, Contextual Theory.
\end{abstract}

Key Words: Christian Communication, Interpersonal Theory, Approach Theory, Contextual Theory.

\begin{abstract}
Abstrak:
Paper ini membahas tentang berbagai pendekatan komunikasi Lintas budaya, Kajian ini berfokus kepada komunikasi Kristen dimana model komunikasi ini ada sedikit perbedaan dengan komunikasi pada umumnya. Komunikasi Kristen memfokuskan pada diskusi tentang kebenaran Injil yang disampaikan dalam lintas budaya. Dalam berkomunikasi seringkali terjadi hambatan disebabkan karena adanya perbedaan karakteristik, bahasa, persepsi, fisik dan budaya. Apabila hambatan tersebut tidak dikelola dengan baik, akan menyebabkan konflik dan berdampak dalam kehidupan seseorang maupun masyarakat. Metode yang penulis gunakan ialah penelitian pustaka yaitu mengemukakan ide dan gagasan dengan cara menganalisis berbagai sumber pustaka. Proses analisis dilakukan dengan cara studi pustaka yakni mengumpulkan sumber berupa jurnal terkait komunikasi lintas budaya serta buku-buku tentang komunikasi sehingga didapati gambaran terkait dengan topik yang dibahas. Adapun hasil yang ditemukan yakni berbagai pendekatan komunikasi lintas budaya yang dapat digunakan antara lain Pendekatan komunikasi Interpersonal; teori pendekatan, Teori Kontekstual.
\end{abstract}

Kata Kunci: Komunikasi Kristen, Teori Interpersonal, Teori Pendekatan, Teori Kontekstual.

Article History

Submit:

Revised:

March $9^{\text {th }}, 2021$

June $29^{\text {th }}, 2021$
Published:

June $29^{\text {th }}, 2021$

\section{Pendahuluan}

Heselegrave (2004) mengungkapkan bahwa manusia merupakan makhluk di bumi yang bisa berkomunikasi dalam bentuk simbol yang tidak ada hubungan dengan apa yang ditunjukkan oleh simbol tersebut, selain dari yang ditentukan oleh pikiran manusia tentang 
apa arti dari simbol itu. Selanjutnya manusia dapat melakukannya melebihi waktu dan ruang, yakni manusia dapat memindahkan informasi kepada orang lain di daerah terpencil atau kepada mereka yang belum dilahirkan. Harianto GP (GP 2012) menambahkan alasan mengapa komunikasi merupakan fundamental, sebab manusia adalah makhluk sosial yang artinya makhluk yang saling membutuhkan satu dengan yang lainnya. Sebagai makhluk sosial, manusia perlu melakukan komunikasi dengan sesama agar dapat memahami dan dipahami oleh orang lain hal ini disebut sebagai proses interaksi.

Hesselgrave (2013) mengutip Richards dengan berkata bahwa komunikasi pada awalnya diperkenalkan oleh beberapa tokoh seni seperti Aristotle, Cicero serta Quintilian. Pada masa mereka komunikasi secara teori disebut retorika, sedangkan praktiknya disebut oratori. Aristotle mengartikan retorika merupakan suatu seni menemukan dalam berbagai kasus sebagai persuasi yang tersedia. Sri Rejeki dalam Keesing mengatakan bahwa komunikasi dapat diartikan sebagai sarana dalam mengirim pesan kepada penerima dalam konteksnya (Rejeki, Rejeki 2010). Harianto GP (2012) juga mengungkapkan bahwa komunikasi ialah sesuatu yang bersifat dinamis, berkelanjutan serta sebuah proses yang bertanggapan. Disebut dinamis karena secara konstan aktif melakukan perubahan. Komunikasi disebut berkelanjutan karena tidak memiliki permulaan yang ditetapkan, diperbaiki atau berakhir tetapi bergerak memutar. Disebut suatu proses yang bertanggapan karena para komunikator yang melakukan komunikasi bertanggungjawab atas keberhasilan dalam komunikasi sehingga komunikator melibatkan banyak unsur dalam berinteraksi.

Berdasarkan beberapa pernyataan di atas, penulis memberikan kesimpulan, komunikasi ialah suatu proses pernyataan antar sesama manusia, yang dinyatakan disini adalah perasaan, ide atau pikiran seseorang kepada yang lain dengan menggunakan bahasa sebagai media atau alat penyalurnya. Harianto GP (2012) mengatakan juga selain bersifat dinamis, komunikasi disebut juga sebagai ilmu karena memiliki objek yang dikaji yaitu upaya manusia dalam menyampaikan pernyataannya kepada orang lain. Selanjutnya kajian terdiri dari satu golongan masalah yang sama tabiatnya yakni isi pernyataannya kepada orang lain. Kemudian keterangan terkait objek harus dapat disusun secara teratur dalam kaitan sebab akibat, disini komunikasi menimbulkan feedback antar komunikator dan komunikan secara sebab akibat.

Dalam bahasa komunikasi terdapat pesan yang disampaikan dan penerima pesan, orang yang menyampaikan pesan disebut komunikator kemudian yang menerima pesan disebut komunikan. Hakikat komunikasi adalah proses pernyataan antar manusia. Yang dinyatakan itu adalah pikiran atau perasaan seseorang kepada orang lain dengan menggunakan Bahasa sebagai alat penyalurnya. Dalam" Bahasa" komunikasi pernyataan dinyatakan pesan (message). Untuk tegasnya, komunikasi berarti proses penyampaian pesan oleh komunikator kepada komunikan jika dianalisis pesan komunikasi terdiri dari dua aspek, pertama isi pesan, kedua lambang. Konkretnya isi pesan itu adalah pikiran atau perasaan, lambang adalah Bahasa.

Komunikasi menjadi suatu pendekatan bagi setiap masyarakat dalam mengutarakan perasaan, pikiran serta menyampaikan informasi yang dimiliki. Ngafifi (2014), dan Muhasim (2017) mengungkapkan bahwa Komunikasi yang dilakukan oleh setiap manusia memberi pengaruh positif maupun negatif kepada setiap orang yang menerimanya. Pengaruh positif 
dirasakan pada saat ini masyarakat dengan mudah berkomunikasi dengan siapa saja meskipun jarak jauh serta waktu yang berbeda sangat didukung dengan kecanggihan teknologi dan komunikasi, hal ini berdampak positif bagi orang yang bekerja dan terpisah jauh dengan anggota keluarga. Namun disisi yang lain terdapat juga dampak negatif dialami oleh suatu keluarga yang setiap harinya bertemu, dan duduk bersama di meja makan namun tidak terjadi komunikasi, disebabkan oleh kesibukan tangan dan mata yang fokus pada handphone. Terdapat istilah menjauhkan yang dekat dan mendekatkan yang jauh, ini menjadi dampak negatif bagi keluarga.

Dalam bersosialisasi seringkali seseorang mengalami hambatan pada saat berkomunikasi dengan orang lain, Kondisi ini dialami oleh semua bidang kehidupan baik sosial, ekonomi, politik maupun budaya, tentu hal tersebut akan memberikan dampak kepada spiritualitas seseorang. Berdasarkan kondisi tersebut, penulis mencoba menelusuri beberapa penelitian terkait dengan hambatan komunikasi yang dialami oleh masyarakat dayak. Hambatan komunikasi yang ditemukan oleh Bahari (Bahari 2014) melakukan kajian tentang model komunikasi budaya berbasis adat di Kalimantan Barat yakni adat Madura dan adat Melayu. Bahari menjelaskan bahwa pola komunikasi yang kerap terjadi dalam penyelesaian konflik antara kedua suku tersebut ialah cenderung mengandalkan penegakan hukum hingga mengesampingkan pendekatan budaya yang menyebabkan mundurnya partisipasi masyarakat terhadap budaya lokal. Dari hasil penelitian tersebut Bahari mengemukakan beberapa hal yakni bila ada konflik berskala kecil perlu adanya musyawarah adat yang dipimpin oleh kepala desa serta para pemangku adat dengan tujuan mencegah meluasnya konflik serta menciptakan perdamaian. Bila cara tersebut tidak bisa ditempuh baru menggunakan hukum nasional. Simon (2013) mengungkapkan bahwa Kalimantan mengalami distrupsi komunikasi awal era reformasi yang menyebabkan konflik dengan melibatkan komunitas agama. Gereja mengalami konflik disebabkan salah satunya karena pola komunikasi dalam berteologi. Salah satu saran yang disampaikan Simon ialah pentingnya merajut Kembali relasi agama sebagai komunitas etnis agar mengedepankan komunikasi lintas agama.

Berdasarkan permasalahan yang terjadi di atas, penulis mencoba melakukan kajian tentang berbagai pendekatan komunikasi lintas budaya bagi Orang Dayak. Hal ini bertujuan untuk meminimalisasikan terjadinya konflik dalam masyarakat dayak sehingga dengan demikian, masyarakat dapat menjalani kehidupan dengan damai.

\section{Metode}

Dalam penelitian ini, penulis menggunakan penelitian Pustaka. Menurut Hamzah (2020) penelitian Pustaka identik dengan melakukan analisis teks. Analisis teks yang dimaksud ialah melakukan penyelidikan terhadap suatu peristiwa, baik dalam bentuk tuisan maupun perbuatan yang diteliti bertujuan agar memperoleh fakta yang tepat serta menemukan teori atau konsep yang ada dalamnya. Creswell (John W 2014) mengingatkan bahwa menggunakan metode ilmiah, maka para peneliti wajib melaksanakan langkah kerja secara ilmiah. Berdasarkan pemaparan Creswell tersebut Hamzah (2019) memaparkan langkah kerja yang perlu dilaksanakan oleh peneliti yakni Mengidentifikasi masalah, Menyusun landasan teori, menetapkan tujuan penelitian, mengumpulkan data serta melakukan analisis dan interpretasi terhadap data. 
Dengan demikian, proses analisis dilakukan dengan cara studi pustaka terhadap berbagai sumber berupa jurnal komunikasi lintas budaya maupun buku-buku tentang komunikasi sehingga didapati gambaran terkait berbagai pendekatan komunikasi lintas budaya. Selanjutnya, dalam penelitian ini ada beberapa proses yang dikerjakan oleh penulis yang menjadi langkah kerja untuk menghasilkan hasil penelitian. Tahap pertama yang dilakukan penulis ialah membaca berbagai sumber yang relevan dengan topik penelitian, menentukan objek penelitian yaitu komunikasi lintas budaya bagi Orang Dayak, selanjutnya penulis melakukan literatur review untuk menajamkan topik yang dibahas. Kemudian setelah itu penulis mendeskripsikan hasil analisis dalam bentuk hasil penelitian. Berikut ini penulis membuat gambar proses kegiatan penelitian.

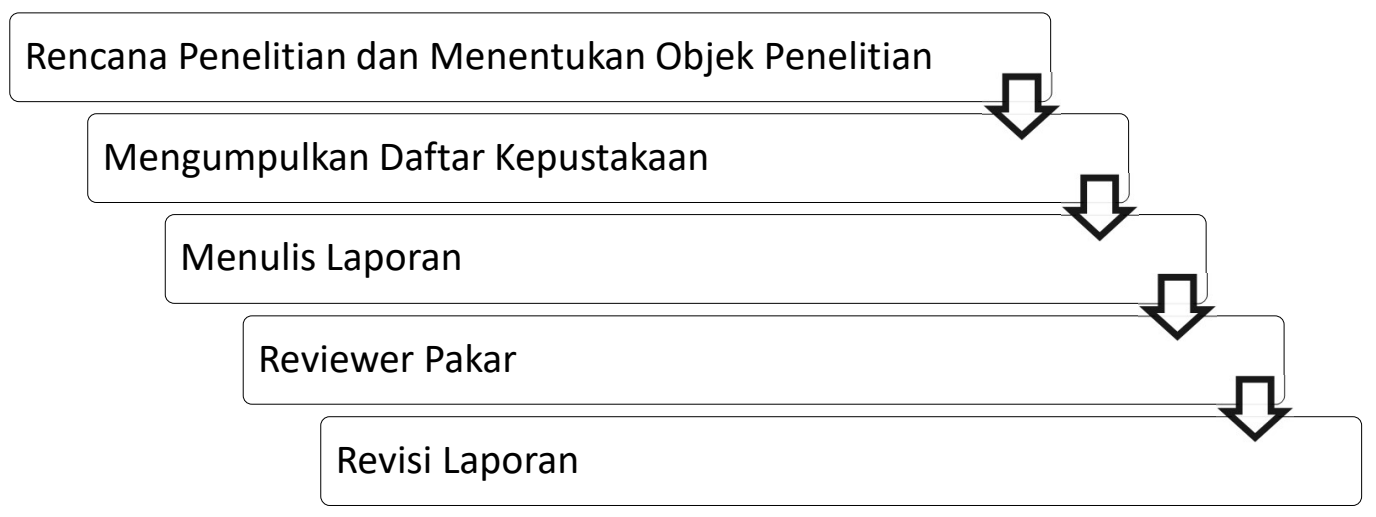

\section{Hasil dan Pembahasan}

\section{Dasar Komunikasi Kristen}

Allah Berinisiatif Berkomunikasi

Harianto GP (GP 2012) mengatakan bahwa komunikasi ialah suatu bingkai atau frame teori dimana komunikator menyampaikan pesan (Message) dengan memakai medium atau tidak kepada komunikan, kemudian komunikan memberikan feedback kepada komunikator, ini yang disebut "frame komunikasi". Bila frame komunikasi ini diberi muatan tentang apa yang hendak disampaikan oleh komunikator kepada komunikan, maka hal itu menjadi bermanfaat dan hidup untuk kehidupan manusia. Demikian pula komunikasi Kristen, Allah yang berinisiatif untuk membangun komunikasi dengan manusia bukan dipengaruhi oleh ide atau gagasan manusia. Allah berinisiatif menciptakan manusia dan melakukan komunikasi dengan manusia, lalu manusia mengecewakan Allah sehingga manusia menjadi berdosa. Tomatala (Tomatala 2018) berpendapat bahwa Kejadian 1 dimulai dengan Allah menyatakan diri sebagai Pencipta, artinya disini Allah mengambil inisiatif pertama dalam penyataan diriNya kepada dunia. Dengan menyatakan diri sebagai pencipta, Allah menunjukkan kehendakNya yang kekal. Bagian ini disebut proses kontekstualisasi Allah kepada manusia. Gambaran tersebut menunjukkan bahwa komunikasi Kristen mengedepankan tentang pemberitaan mengenai kasih Allah yang dinyatakan bagi manusia. 
Allah Memilih untuk berkomunikasi dengan manusia

Manusia merupakan ciptaan yang mulia dan unik. Manusia dikatakan "Serupa dengan Allah..." artinya manusia memiliki relasi yang sangat intim dengan Allah, bahkan Yohanes 1:14 berbunyi: "Firman itu telah menjadi manusia, dan diam di antara kita, dan kita telah melihat kemuliaan-Nya, yaitu kemuliaan yang diberikan kepada-Nya sebagai Anak Tunggal Bapa, penuh kasih karunia dan kebenaran." Allah Mahakuasa, penuh kasih karunia dan kebenaran memilih untuk berinkarnasi menjadi manusia sempurna dan merasakan kelemahan sebagai manusia. Allah melakukan semua ini karena kasi-Nya yang besar kepada manusia (Yohanes 3:16). Harianto (GP 2012) mengatakan bahwa komunikasi Allah melalui inkarnasi Tuhan Yesus menjadi manusia sejati. Tuhan Yesus bukanlah gambaran Allah secara fisik, sekalipun Dia adalah Allah, melainkan gambaran karakter keilahian Allah. Tuhan Yesus menjadi tokoh sentral manusia. Dalam Perjanjian Lama, Allah berkomunikasi memakai bangsa Israel dan dalam Perjanjian Baru, Allah memakai Inkarnasi Tuhan Yesus sebagi pintu keselamatan Kekal. Dari penjelasan tersebut Allah berkomunikasi dengan memakai perantara dalam menyampaikan Misi penyelamatan-Nya bagi umat Manusia.

Tuhan Yesus satu-satunya Jalan keselamatan

Metzger (Metzger 2015) mengatakan Yesus menjadi tokoh sentral berarti semua berita berpusat juga kepada Kristus yaitu berita tentang keselamatan di dalam-Nya. Injil Yohanes. 14:6 berbunyi: "Kata Yesus kepadanya, Akulah Jalan dan kebenaran dan hidup. Tidak ada seorangpun yang datang kepada Bapa kalau tidak melalui Aku" Ayat paralel dalam Kisah Para Rasul. 4:12 berbunyi: "Dan keselamatan tidak ada di dalam siapapun juga selain di dalam Dia, sebab di bawah kolong langit ini tidak ada nama lain yang diberikan kepada manusia yang olehnya kita dapat diselamatkan." Kedua ayat tersebut dengan gamblang menyampaikan tentang keselamatan hanya dan melalui Yesus Kristus. Dalam komunikasi Kristen isi berita yang menjadi poin penting ialah menyampaikan Injil yaitu untuk memperoleh keselamatan hanya ada dalam Yesus Kristus. Pemberitaan Injil tidak sama dengan mengkristenisasikan seseorang melainkan menginformasikan tentang keselamatan jiwa manusia.

Orang Kristen dipilih untuk suatu hak istimewa memberitakan tentang Yesus

Manusia di panggil untuk diselamatkan dari dosa. 1 Petrus 1:18 berbunyi: "Sebab kamu tahu, bahwa kamu telah ditebus dari cara hidupmu yang sia-sia yang kamu warisi dari nenek moyangmu itu bukan dengan barang yang fana, bukan pula dengan perak atau emas, melainkan dengan darah yang mahal yaitu darah Kristus yang sama seperti darah anak domba yang tak bernoda dan takbercacat." Selain memberitakan tentang keselamatan, komunikasi kristen juga memberikan kesadaran bahwa manusia telah jatuh dalam dosa, dan takluk dibawah kuasa dosa. Hanya oleh kuasa Darah Kristus yang telah menebus hidup manusia dan membayar lunas dosa manusia sehingga menjadi suci dan dibenarkan Allah. Untuk dapat menerima pembenaran dari Kristus, Seseorang harus mengalami pertobatan. Dalam komunikasi Kristen, komunikator perlu menyampaikan secara jelas bahwa panggilan keselamatan ini berlaku bagi siapa saja, panggilan ini tidak memaksa namun membutuhkan tanggapan dan respon yang serius dari manusia sendiri. Ketika manusia sudah lahir baru, 
manusia diberikan tugas istimewa yaitu pergi jadikan semua bangsa murid Yesus, melakukan baptisan dalam nama Bapa, Anak dan Roh Kudus, mengajar mereka melakukan segala yang diperintahkan-Nya (Matius 28:19-20). Perintah ini bukan hanya perintah biasa, melainkan perintah yang disertai dengan janji yaitu Menyertai setiap pemberita senantiasa sampai kepada akhir zaman.

Setelah memahami tentang berita pertobatan dan keselamatan tersebut, seorang komunikator menyampaikan tugas yang diemban yakni orang Kristen dapat memahami kehidupan, pengajaran serta pelayanan Tuhan Yesus melalui Alkitab. Orang Kristen dituntut untuk hidup sesuai dengan pengajaran Kristus dan meneladani karakter-Nya yakni mengasihi semua orang (GP 2012). Muhtadi (Muhtadi 2019) menjelaskan bahwa perbedaan agama sekalipun tidak boleh menghalangi rasa empati untuk meng-ekspresikan kasih dan solidaritas sebagai sesama manusia. Rasa empati ini tumbuh karena kesadaran dari dalam diri manusia yang tulus iklas. Hesselgrave (Hesselgrave 2004) juga mengungkapkan bahwa orang Kristen diutus menjadi Misionari untuk menjadi komunikator melakukan komunikasi dengan orang lain dalam konteks yang lebih luas.

Roh Kudus bekerja dalam proses komunikasi Kristen

Peran Roh Kudus dalam komunikasi Kristen sangat penting bahkan hal ini menjadi tolak ukur berhasil atau tidaknya komunikasi itu berjalan. Harianto (GP 2012) menegaskan bahwa meskipun seseorang bisa mengetahui kehidupan dan pengajaran Yesus melalui Alkitab. Namun tidak semua orang bisa memahami Tuhan Yesus apabila Roh Kudus tidak bekerja dalam hatinya. Komunikator Kristen perlu menyadari bahwa kuasa Roh Kudus yang memberikan kemampuan kepada manusia untuk mengenal dan memahami siapakah Tuhan Yesus sesungguhnya. Paulus menulis kepada Timotius demikian: "Segala Tulisan yang diilhamkan Allah memang bermanfaat untuk mengajar, untuk menyatakan kesalahan, untuk memperbaiki kelakuan dan untuk mendidik orang dalam kebenaran. Dengan demikian tiaptiap kepunyaan Allah diperlengkapi untuk setiap perbuatan baik. (2 Timotius 3:15-17 TB)." Ayat di atas memberikan penegasan bahwa peran Roh Kudus dalam komunikasi Kristen sangat penting dan bersifat mutlak. Tomatala (Tomatala 2000) menjelaskan bahwa pembawa berita Injil perlu terus belajar untuk peka terhadap pimpinan Roh Kudus yang mengarahkan pembawa berita kedalam suatu realitas yaitu apa yang real sesungguhnya, para penginjil harus memiliki kesadaran budaya orang lain dalam rangka menjadi komunikator. Dengan demikian, selain dari peran Roh Kudus dalam komunikasi, Orang Kristen juga perlu juga belajar dan berhikmat dalam melakukan apa yang mesti dikerjakan.

\section{Syarat Menjadi Komunikator Kristen.}

Komunikasi yang baik dipengaruhi oleh komunikator yang baik juga. Komunikator ialah seorang yang menyampaikan isi pesan, pernyataan kepada pendengar atau disebut komunikan. Komunikator mengawali proses komunikasi sebaiknya hendaklah berkomunikasi dan mempunya motif motivasi atau sasaran komunikasi (Rhozely, Wirman, g Firdaus 2020). Dengan demikian dalam ber-komunikasi, komunikator selalu mempunyai tujuan komunikasi sendiri. Situmeang (2020) dan (KETA 2020) mengatakan bahwa komunikator Kristen perlu menyajikan ide yang benar serta kreatif sehingga orang dapat mengerti pesan yang 
disampaikan. Meskipun hal ini ada tantangan yang dialami yakni selain Era revolusi Industri, 4.0 namun ada juga pandemi Covid 19 yang menyebabkan orang banyak tidak lagi dapat menjalin komunikasi seperti biasanya, semua diarahkan pada kebiasaan baru atau protokol kesehatan.

Effendi (1990) dan Liliweri (2003) memaparkan bahwa seorang komunikator Kristen perlu memperhatikan beberapa hal berikut yaitu pertama, komunikator sebagai sumber pernyataan umum yang disampaikan misalnya Individual (perseorangan), intitusional (seperti redaktur surat kabar, dst). Kedua, komunike adalah pernyataan umum (pesan) yang dilancarkan berupa: verbal simbol yang diucapkan, tertulis atau tercetak, non verbal simbol yang terlukis, terdengar (sirine, peluit, suit dst). Menanggapi hal itu, GP (GP 2012) memberikan beberapa persyaratan penting bagi komunikator untuk melakukan komunikasi Kristen. Pertama, Memiliki karakter Kristus. Karakter dimaksud ialah ada integritas diri, kedewasaan rohani, berani serta berhikmat, adanya kematangan psikologi, kerja, mentalitas positif dan komitmen. Memiliki karakter Kristus artinya berbicara selalu berkaitan dengan perintah-perintah Kristus mengenai kabar baik yang terus menerut dikomunikasikan kepada dunia. Kedua, memiliki pengetahuan yang komprehensif memiliki kemampuan serta keterampilan yang bersifat sosial atau berhubungan dengan orang. Ketiga, memiliki tanggungjawab yang tinggi kepada Allah, gereja, diri sendiri dan dunia. Keempat, hidup punya sasaran yang memberikan motivasi dan dinamika bagi hidup serta kerja.

\section{Tahap komunikasi}

\section{Tahap 1. Transmisi.}

Transmisi terjadi dalam komunikasi apabila suatu pesan sampai kepada pendengar atau mata orang, yakni pesan itu didengar, dilihat, atau dibaca oleh para pendengar (Caropeboka 2017). Hesselgrave (Hesselgrave 2013) menambahkan bisa saja didengar atau dilihat namun tidak ditanggapi. Bila sumber di dalam kebudayaan " $X$ " menulis berita dalam bahasa mereka, lalu berita itu melewati tantangan atau sekat kultural dan sebagian besar dan sudah pasti melewati jaringan atau sekat kultural yang sebagian besar bersifat pasti mengenai cara yang mana berita itu akan dipelajari oleh responden di dalam kebudayaan "Y" jaringan ataupun sekat ini memiliki tujuh dimensi yang secara bersamaan mempengaruhi berita tersebut.

\section{Tahap 2. Penerima}

Penerima atau tahap penerima terjadi apabila sebuah pesan atau bukan hanya ketika di mata atau di telinga pendengar, melainkan juga sampai ke otaknya yaitu ia memperhatikan senam ini. Dazali dan Awang (2016) mengungkapkan bahwa komunikasi memiliki hubungan erat dengan kepiawaian seseorang agar pesan yang disampaikan dapat diterima oleh penerima pesan.

\section{Tahap 3. Pengertian}

Pengertian (Understanding) terjadi apabila seseorang memberi perhatian pada pesan yang disampaikan oleh seseorang. Namun hal itu tidak menjamin bawha orang tersebut 
memahami isinya. Proses komunikasi terjadi bila orang lain dapat memahami pesan yang disampaikan oleh komunikator.

Tahap 4. Tanggapan.

Tanggapan (Response) terjadi ketika seseorang menerima, menolah atau menunda suatu keputusan. Dalam mengkomunikasikan kebenaran Firman Tuhan, Roh Kudus bekerja supaya orang mengerti dan menerima maksud komunikator. Disinilah keunikan komunikasi Kristen yakni bahwa peran Roh Kudus bekerja baik dalam komunikator maupun komunikan.

\section{Berbagai Pendekatan komunikasi lintas budaya Bagi Orang Dayak}

Pendekatan Komunikasi Interpersonal

Orang dayak memiliki sifat yang cenderung keras karena dipengaruhi beberapa faktor, sifat yang cenderung keras menimbulkan pola komunikasi yang blak-blakan serta sedikit acuh tak acuh (Humannira 2016). Cara berkomunikasi ini perlu dipahami oleh seorang komunikator Kristen apabila melakukan komunikasi dengan orang dayak. Tahap yang dapat digunakan ialah pendekatan personal. Pada tahap ini komunikator perlu sadar bahwa orang dayak memiliki kultur yang berbeda dengan yang lainnya.

Seorang komunikator Kristen perlu menguasai komunikasi interpersonal atau komunikasi pribadi. Hesselgrave mengatakan bahwa dari sudut pandang Kristen, komunikasi interpersonal perlu bagi manusia karena perlu berkomunikasi, bukan hanya sebagai responden namun didalam proses menyiarkan dan memperkuat pesan-pesan Kristen yang dikomunikasikan khususnya media massa. Komunikasi interpersonal terjadi diantara dua pribadi, bersifat langsung dan sering dalam bentuk percakapan baik lisan maupun tulisan. Pada prinsipnya komunikasi ini berlangsung secara berhadapan muka (Face to face) atau melalui medium tertentu misalnya telepon, WhatsApp, Telegram, dst. Adapun bentuk komunikasi ini bersifat dialog atau diskusi dua arah yang memiliki efektivitas tinggi dalam proses transmisi informasi.

Harianto GP (2012) memberikan beberapa hal penting tentang kunci komunikasi interpersonal agar efektif yakni pertama seorang komunikator bersedia untuk mendengar dengan sikap empatik, mengerti orang lain secara objektif (sesuai dengan kondisi yang sebenarnya). Kedua, komunikator perlu belajar membuat diagnosis sebelum memberi penguraian dan penjelasan ataupun suatu jawaban terhadap apa yang didengar dari komunikan. Ketiga, Perlu bersikap berhati-hati terhadap pola respon otobiografi, dengan cara buatlah evaluasi terhadap apa yang dihadapi sebelum menetapkan setuju atau tidak setuju, ambillah sikap kritis atau curiga positif dengan mengembangkan prasangka bahwa ada sesuatu yang tersembunyi pada diri orang yang dihadapi dan kembangkanlah pertanyaan untuk menggalinya; berikanlah nasiat yang didasarkan atas pengalaman atau buatlah penjelasan dengan memakai contoh orang dengan motif batin tertentu sambil mengkaitkan pada motif serta perilaku sendiri untuk memperoleh kejelasan tentang sikap orang yang dihadapi. Keempat, komunikator berupaya memahami pengertian serta persepsi orang yang dihadapi. Kelima, setelah komunikator mengerti komunikan, upayalah untuk dimengerti orang yang dihadapi dengan membuka dan menempatkan diri dalam terang agar dapat dimengerti 
orang lain dengan baik. Dengan demikian, seorang komunikator Kristen penting untuk memperhatikan lawan bicara serta situasi lingkungan dimana ia berada.

\section{Teori Pendekatan}

Pada umumnya manusia memerlukan relasi antar satu dengan yang lain. Hal ini membutuhkan pendekatan untuk mengenal seseorang lebih dekat, demikian juga dengan orang dayak, untuk menjalin relasi dengan mereka seorang komunikator perlu memiliki sikap yang terbuka sehingga orang dayak dapat menerima dengan baik (Abdullah 2015). Hidayat (2016) menambahkan bahwa Sikap terbuka ini akan memudahkan seseorang melakukan pendekatan untuk bisa berkomunikasi.

Donald A. McGavran (1990) memaparkan tentang teori pendekatan dengan beranjak dari beberapa hal yaitu pertama, kekuatan dalam mengubah seseorang menjadi Kristen tergantung pada ukuran perubahan yang dimaksud oleh orang yang melakukan perubahan. Kedua, ada suatu kehidupan masyarakat disuatu tempat yang terhalangi sungai, untuk melakukan perubahan pada masyarakat tersebut, komunikator Kristen perlu membangun jembatan dan menyeberanginya. Teori ini menekankan pada isi kurikulum yang bersifat perencanaan untuk dapat bertindak pada konteks.

Untuk mengkomunikasikan Injil kepada orang lain, teori pendekatan memberikan beberapa hal yaitu: pendekatan doktrin, pendekatan kebutuhan, dan pendekatan persahabatan. Pendekatan doktrin ada tiga model yakni a) Eksklusif artinya hanya satu pintu keselamatan yaitu Tuhan Yesus, tidak ada jalan lain kecuali melalui Yesus. b) inklusif yaitu hanya satu pintu keselamatan, yaitu Tuhan Yesus. namun jalan untuk sampai kepada Tuhan Yesus dapat melalui berbagai hal. c) pluralisme agama dimana keselamatan ada dalam agama-agama lain. Selanjutnya, Yuliana (Mendari 2010; Yuliana 2019) mengungkapkan tentang pendekatan kebutuhan dirumuskan oleh Abraham $\mathrm{H}$ Maslow dengan memberikan gambaran tentang kebutuhan manusia dalam sebuah diagram piramida yang dikenal dengan "Piramida kebutuhan."

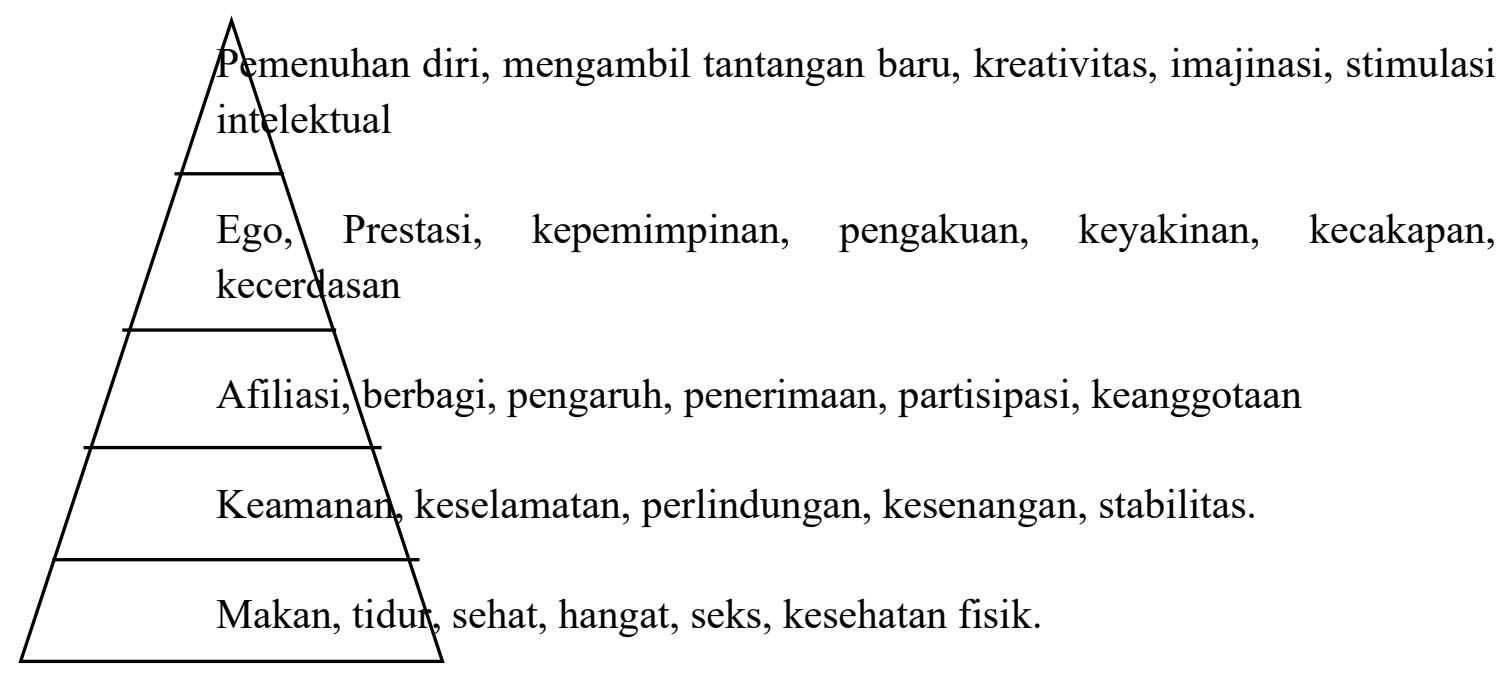

Berdasarkan gambar di atas, Maslow memberikan penjelasan kepada lima kebutuhan manusia, dimulai dari yang luas, akhirnya mengerucut. Pemahaman akan tingkat kebutuhan manusia ini dapat digunakan sebagai sarana pendekatan kepada komunikan. Komunikator 
harus jeli melihat sampai tingkat manakah kebutuhan komunikan dan pada tingkat itulah komunikator hendaknya menjawab kebutuhannya. Dengan demikian, beranjak dari skema kebutuhan tersebut, seorang komunikator Kristen penting untuk memperhatikan hal itu sebagai sebuah sarana dalam menjalin komunikasi.

Berikutnya pendekatan persahabatan, komunikator harus membangun jembatan persahabatn untuk menghubungkan dirinya dengan komunikan. Jembatan itu ialah cinta kasih dan menunjukkan kepada mereka bahwa komunikator menaruh perhatian kepada komunikan. Paulus memberikan pernyataan bahwa: "Bagi semua orang aku telah menjadi segala-galanya, supaya aku sedapat mungkin memenangkan beberapa orang dari antara mereka" (1 Kor. 9:22) Paulus ingin berusaha menyelami kebutuha perindividu, disinilah proses komunikasi berjalan dua pihak. Komunikator perlu mencari serta memanfaatkan titik-titik tertentu sebagai penghubung untuk membangun persahabatan, seperti misalnya saat sukacita, kegemaran, acara pernikahan, kematian, kesulitan keuangan, acara ulang tahun, kesusahan, tindakantindakan kebajikan, kasih atau ucapan-ucapan selamat. Maksud pendekatan persahabatan ialah Ketika seorang komunikator Kristen bertemu dengan orang yang baru di kenal, maka penting untuk menjalin persahabatan agar dapat berkomunikasi dengan baik dengan demikian akan memudahkan untuk membicarakan hal-hal yang lebih dalam lagi termasuk tentang hal bersifat rohani.

\section{Teori Kontekstualisasi}

Komunikasi Kristen dapat berhasil bila komunikator dan komunikan berada dalam konteks yang sama dan menyatu. Harianto (2012) menjelaskan bahwa itulah ruang kebudayaan yang sama dan menyatu antar komunikator dan komunikan. Dalam ruang itu juga suatu berita disampaikan lewat berbagai cara, baik verbal maupun non verbal, lewat beragam sarana dan media. Menjalin komunikasi dengan orang dayak, sangat diperlukan pendekatan kontekstualasi, mengingat orang dayak memiliki budaya yang kompleks (Satria. 2020). Dengan demikian dalam komunikasi Kristen seorang komunikator perlu memastikan bahwa pendengar dapat memahami dengan baik berita yang disampaikan sehingga pendengar bisa memberikan feedback terhadap berita yang didengarnya.

Komunikator dapat menggunakan materi budaya yang dapat diterima budaya komunikan, menggunakan konsep bahasa yang dapat diterima oleh bahasa komunikan. Kemudian kontekstualisasi bentuk dan isi. Paulus berkontekstualisasi dengan cara komunikasi verbal dan feedbacknya ada yang menolak dan ada yang bertobat seperti Dionisius yang anggota majelis Areopagus, kemudian Damaris seorang wanita. Pada penjelasan ini Paulus (komunikator) - Pesan (Firman Allah) - Pendengar (Masyarakat Athena di sekitar Areopagus). Model kontekstualisasi Paulus menggunakan dialog "Allah yang tidak dikenal (Kis. 17:16-34). Dalam bagian itu, Paulus memperkenalkan arti baru "Allah yang tidak dikenal" bukanlah dewa bagi orang Athena, tapi Paulus menjelaskan bahwa Allah itu tidak jauh tetapi dekat. Dia adalah segala yang ada dan yang hidup (Kis. 17:27) dan seterusnya, lebih lanjut, Paulus mengajak mereka bertobat (Kis. 17:30) kemudian mengungkapkan hal kebangkitan Kristus sebagai bukti semua manusai akan menghadapi pengadilan ilahi (Kis. 17:31) sedangkan form yang dipakai Paulus ialah Religi dan budaya yang ada.(GP 2012). Budiman (ث.د) memberikan beberapa langkah kontekstualisasi, yaitu ada tiga sikap yang 
dapat dilakukan untuk kontekstualisasi terhadap budaya lama (misalnya upacara-upacara adat, seni, musim dan isu-isu penting). Pertama "menolak" berarti menolak kontekstualisasi, dampaknya (1) Injil menjadi asing, (2) budaya lama tetap dilaksanakan, tetapi secara tersembunyi (sinkretisme). Kedua, "Pertimbangan akomodasi" (kontekstualisasi yang alkitabiah) caranya ialah (1) cari info tentang budaya lama, (2) pelajari penyataan Alkitabiah, (3) evaluasi unsur lama (memakai, mengubah, atau membuang) dari sudut terang Alkitab dan pimpinan Roh Kudus, (4) Membuat rumusan kontekstual yang alkitabiah untuk dilkaukan. Ketiga,"terima saja" (kontekstualisasi - sinkretisme yang alkitabiah).

\section{Kesimpulan}

Komunikasi memiliki peranan penting dalam setiap manusia, bahkan komunikasi bersifat fundamental. Salah berkomunikasi menimbulkan dampak yang serius bagi individu maupun masyarakat. Dampak tersebut dapat menimbulkan hal positif maupun negatif, bisanya dampak negatif terjadi karena ada hambatan yang disebabkan oleh perbedaan karakteristik, bahasa, persepsi, fisik dan budaya. Apabila hambatan tersebut tidak dikelola dengan baik, akan menyebabkan konflik dan berdampak dalam kehidupan seseorang maupun masyarakat. Penting untuk memahami pendekatan komunikasi lintas budaya kepada orang dayak yakni (1) Melakukan pendekatan interpersonal atau pendekatan pribadi artinya seorang komunikator perlu melakukan pendekatan secara pribadi dengan orang dayak sebelum menyampaikan pesan, pendekatan ini perlu karena orang dayak sangat memiliki karakteristik yang agak keras. Seorang komunikator Kristen perlu memahami dengan baik supaya dapat diterima. (2) selain pendekatan interpersonal, seorang komunikator perlu melakukan pendekatan budaya dengan orang dayak karena mereka memiliki kebudayaan yang kompleks dan budaya tersebut sangat dijaga. (3) pendekatan kontekstual artinya seorang komunikator perlu menyesuaikan diri dengan kebiasaan atau kearifan lokal orang dayak, termasuk makan makanan mereka karena orang dayak menjunjung tinggi kearifan lokal serta bentuk penghargaan mereka kepada tamu melalui kegiatan budaya.

\section{Daftar Rujukan}

Abdullah, Yudi. 2015. Komunikasi Sebuah Introduksi. Deepublish.

Bahari, Yohanes. 2014. "Model komunikasi lintas budaya dalam resolusi konflik berbasis Pranata Adat Melayu dan Madura di Kalimantan Barat". Jurnal Ilmu Komunikasi 6(1).

Budiman, R. L. Pelayanan Lintas Budaya Dan Kontekstualisasi.

Caropeboka, Ratu Mutialela. 2017. Konsep dan aplikasi ilmu komunikasi. Penerbit Andi.

Christianto Simon, John. 2013. "Konflik dan Dilema 'Gereja Suku' Mengurai Relasi Agama, Etnisitas dan Budaya Dalam Konflik Sosial di Kalimantan Sebagai Upaya Gereja Menemukan Kembali 'Rasa Asia"'. journal-theo.ukdw.ac.id 37(2).

Dazali, Nurul Salmi Mohd, g Mohd Isha Awang. 2016. "Tahap kemahiran komunikasi dalam kalangan pelajar sarjana muda pendidikan IPTA di utara semenanjung Malaysia". Jurnal Pendidikan Bahasa Melayu 4(2):44-56. 
Effendy, Onong Uchjana. 1990. Ilmu komunikasi teori dan praktek. Remaja Rosdakarya.

GP, Harianto. 2012. Komunikasi Dalam Pemberitaan Injil. Yogyakarta: ANDI.

Hamzah, Amir. 2019. Metode Penelitian Kualitatif (Rekonstruksi Pemikiran Dasar serta Contoh Penerapan Pada Ilmu Pendidikan, Sosial dan Humaniora). Malang: Literasi Nusantara.

Hamzah, Amir. 2020. Metode Penelitian Kualitatif (Rekonstruksi Pemikiran Dasar Natural Research). Malang: Literasi Nusantara.

Hesselgrave, David J. 2004. Communicating Christ Cross-Culturally. Malang: Literatur Saat.

Hesselgrave, David J. 2013. Communicating Christ Cross-Culturally. 2 b. Malang: Literatur SAAT.

Humannira, Raden Regia. 2016. "Proses Internalisasi Nilai Kearifan Lokal Masyarakat Banten Pada Mahasiswa yang Tergabung dalam Organisasi Kedaerahan (Studi Deskriptif di Organisasi Kedaerahan Perhimpunan Mahasiswa Banten Bandung)".

John W, Creswell. 2014. Reseach Design Pendekatan Kualitatif, Kuantitatif dan Mixed. 3 b. Yogyakarta: Pustaka Pelajar.

KETA, Kornelius K. F. 2020. "Pengaruh Media Sosial Terhadap Komunikasi Interpersonal Orangtua Dan Remaja".

Liliweri, Alo. 2003. Makna budaya dalam komunikasi antarbudaya. LKiS Pelangi Aksara.

McGavran, Donald A. 1990. Understanding Church Growth. Grand Rapids: Publishing Company.

Mendari, Anastasia Sri. 2010. "Aplikasi teori hierarki kebutuhan Maslow dalam meningkatkan motivasi belajar mahasiswa". Widya Warta: Jurnal Ilmiah Universitas Katolik Widya Mandala Madiun 34(01):82-91.

Metzger, Will. 2015. Beritakan Kebenaran: beritakan kebenaran Injil yang seutuhnya bagi pribadi yang seutuhnya oleh pribadi-pribadi yang seutuhnya. Surabaya: Momentum.

Muhasim, Muhasim. 2017. "Pengaruh Tehnologi Digital terhadap Motivasi Belajar Peserta Didik". Palapa 5(2):53-77.

Muhtadi, Asep S. 2019. "Komunikasi Lintas Agama: Mencari Solusi Konflik Agama". Conference Proceeding ICONIMAD 27.

Nadya, Karlina, و Dasrun Hidayat. 2016. "Makna hubungan antarpribadi melalui media online tinder". Jurnal Ilmu Komunikasi 3(1).

Ngafifi, Muhamad. 2014. "Kemajuan teknologi dan pola hidup manusia dalam perspektif sosial budaya". Jurnal Pembangunan Pendidikan: Fondasi dan Aplikasi 2(1).

Rejeki, M. C. Ninik Sri, g M. C. Ninik Sri Rejeki. 2010. "Perspektif Antropologi dan Teori Komunikasi: Penelusuran Teori-teori Komunikasi dari Disiplin Antropologi". Jurnal Ilmu Komunikasi 7(1). 
Rhozely, Metta, Welly Wirman, g Muhammad Firdaus. 2020. "Komunikasi Persuasif Pembina Dalam Meneguhkan Keyakinan Mualaf Pada Mualaf Center Pekanbaru". Jurnal Ilmu Komunikasi 9(3):363-81.

Satria, Rachmat, Nur Amaliyah Hanum, Elvia Baby Shahbana, Achmad Supriyanto, g Nurul Ulfatin. 2020. "Landasan Antropologi Pendidikan dan Implementasinya Dalam Pembangunan Indonesia". Indonesian Journal of Social Science Education (IJSSE) 2(1):49-65.

Situmeang, Ilona V. Oisina. 2020. "Strategi Komunikasi Pemimpin Adat Bali di Era New Normal".

Tomatala, Y. 2018. Teologi Kontekstualisasi (Suatu Pengantar). Malang: Gandum Mas.

Tomatala, Yakob. 2000. Teologi Kontekstualisasi. Malang: Gandum Mas.

Yuliana, Asnah. 2019. "Teori Abraham Maslow dalam Pengambilan Kebijakan di Perpustakaan". LIBRARIA: Jurnal Perpustakaan 6(2):349-76. 